\title{
Monitoring and identification of pollutant groups of the Lagoa Mirim
}

Located on the Atlantic coast of South America, the Lagoa Mirim watershed occupies an area of 47,362 km2 of direct contribution and 55,110 km2 including the coastal strip. It has a high pollution index of agricultural origin because of the territorial extension of the areas used for this purpose. Another important factor that contributes to the pollution of this lagoon is the launching of untreated urban and industrial sewage into the São Gonçalo watercourse, where Lagoa Mirim interconnects with Lagoa dos Patos. This study aimed to use multivariate statistical methods, such as FA/PCA, to analyze the water quality of this water resource. Water samples were collected in 2014, 2015 and 2016 at eight monitoring points of Lagoa Mirim. Ten parameters of water quality were analyzed. In general, the variables showed a strong correlation with each other. There were four main components of quality for the water body studied with an accumulated explained variance of $80.24 \%$. These components are mainly related to agricultural and urban pollution. The results attest to the relevance of using statistical methods for the monitoring of this lagoon. They also provide an idea of the processes that influence the water quality.

Keywords: Monitoring; Lagoa Mirim; Correlation matrix.

\section{Monitoramento e identificação de grupos poluentes da Lagoa Mirim}

Localizada na costa atlântica da América do Sul, a bacia hidrográfica da Lagoa Mirim ocupa $47.362 \mathrm{~km}^{2}$ de aporte direto, e $55.110 \mathrm{~km}{ }^{2}$ quando inclusa a faixa litorânea. Ela apresenta um elevado índice de poluição de origem agrícola em consequência da extensão territorial das áreas utilizadas para tal fim. Outro importante fator que contribui para a poluição dessa lagoa é o lançamento de esgoto urbano e industrial não tratado no canal São Gonçalo, onde ocorre a interligação da Lagoa Mirim à Lagoa dos Patos. Sendo assim, esse estudo teve como objetivo a aplicação do uso de métodos estatísticos multivariados tais como a AF/ACP para analisar a qualidade das águas desse recurso hídrico. Para isto, foram realizadas coletas de amostras de água ao longo dos anos 2014 , 2015 e 2016 em 8 pontos de monitoramento da Lagoa Mirim as quais foram analisados 10 parâmetros de qualidade hídrica. Pode-se observar que, de forma geral, as variáveis apresentaram forte correlação umas com as outras. Foram encontrados 4 componentes principais de qualidade para o corpo hídrico aqui estudado, com uma variância explicada acumulada de $80,24 \%$, que são relativos a, principalmente, poluição agrícola e de origem urbana. Esses resultados atestam a relevância do uso de métodos estatísticos para o monitoramento dessa Lagoa, bem como dão uma ideia dos processos que influenciam nas qualidades de suas águas.

Palavras-chave: Monitoramento; Lagoa mirim; Matriz de correlação.

Topic: Engenharia Ambiental

Reviewed anonymously in the process of blind peer
Received: 09/05/2020

Approved: 04/06/2020
Marlon Heitor Kunst Valentini (iD Universidade Federal de Pelotas, Brasil http://lattes.cnpq.br/6499660114940771 http://orcid.org/0000-0003-3183-5142 marlon.valentini@hotmail.com

Gabriel Borges dos Santos Universidade Federal de Pelotas, Brasil http://lattes.cnpq.br/8502930511377553 http://orcid.org/0000-0002-0013-0134 gabrielwxsantos@hotmail.com

Victoria Huch Duarte (10)

Universidade Federal de Pelotas, Brasil http://lattes.cnpq.br/1244963610234373 http://orcid.org/0000-0002-8780-1227 victoriahduarte@gmail.com

\section{Andressa Dröse \\ Universidade Federal de Pelotas, Brasil http://lattes.cnpq.br/5969881829780262 \\ andresa_drose@hotmail.com \\ Beatriz Müller Vieira (ic) \\ Universidade Federal de Pelotas, Brasil http://lattes.cnpq.br/7971506885058825 http://orcid.org/0000-0002-0813-2417 biamvieira14@hotmail.com \\ Francine Vicentini Viana (iD) \\ Universidade Federal de Pelotas, Brasil http://lattes.cnpq.br/0219375029813785 http://orcid.org/0000-0001-9881-0965 \\ fravivi@gmail.com}

\section{Marília Guidotti Corrêa (DD \\ Universidade Federal de Pelotas, Brasil http://lattes.cnpq.br/2113299633932476 http://orcid.org/0000-0001-9091-6001 mariliaguidotti@yahoo.com.br \\ Hugo Alexandre Soares Guedes Universidade Federal de Pelotas, Brasil http://lattes.cnpq.br/5120976859905217 http://orcid.org/0000-0002-3592-9595 hugo.hydro@gmail.com \\ Willian Cézar Nadaleti (ic) \\ Universidade Federal de Pelotas, Brasil http://lattes.cnpq.br/4670559561277136 http://orcid.org/0000-0002-4727-4127 williancezarnadaletti@gmail.com}

\section{Bruno Müller Vieira (iD) \\ Universidade Federal de Pelotas, Brasil http://lattes.cnpq.br/1885554662703620 http://orcid.org/0000-0002-9615-3778 bruno.prppg@hotmail.com}

\section{Referencing this:}

VALENTINI, M. H. K.; SANTOS, G. B.; DUARTE, V. H.; DRÖSE, A.; VIEIRA, B. M.; VIANA, F. V.; CORRÊA, B. L.; GUEDES, H. A. S.; NADALETI, W. C.; VIEIRA, B. M.. Monitoring and identification of pollutant groups of the Lagoa Mirim. Revista Ibero Americana de Ciências Ambientais, v.11, n.4, p.227-235, 2020. DOI: http://doi.org/10.6008/CBPC21796858.2020 .004 .0020 


\section{INTRODUCTION}

The watershed of Lagoa Mirim is located on the Atlantic coast of South America. It occupies an area of $47,362 \mathrm{~km}^{2}$ of direct contribution, and $55,110 \mathrm{~km}^{2}$ including the coastal strip, in which the main swamps of the region are inserted, including Lagoa Mangueira. They are connected exclusively to Lagoa Mirim by the Taim hydrological system (STEINKE, 2008).

The Lagoa Mirim has a high pollution index mainly due to agricultural activities resulting from the territorial extension of the areas used for this purpose. The contribution of untreated urban and industrial sewage in the São Gonçalo watercourse is also relevant. This watercourse connects Lagoa Mirim with Lagoa dos Patos (SOUZA, 2013).

One of the main problems resulting from high pollution is the eutrophication of water resources. Concerning Lagoa Mirim, Fia et al. (2009), in their samplings, found concentrations of phosphorus higher than the limit established by National Council of the Environment (CONAMA) in its Resolution No. 357 of 2005 for class 2 watercourses. The values found by these researchers indicate strong indexes of eutrophication in Lagoa Mirim (FIA et al., 2009).

Such pollution must be reduced,therefore it is extremely important that it be monitored, that its specific pollution sites be known and treated, and that the pollutant group in question be identified. Knowledge of interactions is important so that pollution sources can best be dealt with (PIMENTA, 2016). In times of great urban population concentration, high pollution, inadequate disposal of waste and effluents, and high use of agrochemicals in agricultural plantations, the concern with water quality is increasing (MARMONTEL et al., 2015).

Lagoa Mirim is one of the most important freshwater lagoons in Brazil and in South America. With approximately 375 thousand hectares of water surface, it is the second largest water body with lacustrine characteristics in Brazil, surpassed only by the Lagoa dos Patos (OLIVEIRA et al., 2015).

The watershed of Lagoa Mirim is a valuable source of fishery resources for a large number of families who live on artisanal fishing and suffer a strong anthropogenic pressure due to agropastoral activities developed in their surroundings, both in the Brazilian and Uruguayan territory, through extensive crops areas with irrigated rice. In addition, it also has important ecological features associated with humid environments, especially Banhado do Taim, located on its east bank (STEINKE, 2008). The basin of Lagoa Mirim, therefore, has great social, economic and environmental potential, and should whenever possible allow the development of all these areas equally.

Agribusiness predominates and suppresses the economic demands of the region. In Brazil alone, more than 40,000 hectares of rice are planted per year using the water from this watershed for irrigation (STEINKE, 2008). However, with the great use of agrochemicals and the high need for irrigation, economic development hides the importance of the preservation of natural resources and biodiversity. Therefore balance in it is required (STEINKE, 2008).

Some water bodies in the Lagoa Mirim watershed cut across regions with intense agricultural activity, 
such as the São Gonçalo Canal, which presents irrigated rice crops on both banks. It is a significant water resource used by rice farmers in the Pelotas region. As in many watercourses, there is also return of water used in rice fields (ALBERTONI et al., 2017). There is still the problem that the São Gonçalo watercourse receives part of the effluents from the city of Pelotas, since the city has a sewage network that serves only $67 \%$ of the population, including industries, and only $40 \%$ of the sewage collected is treated (SILVA, 2007). In addition, much of this wastewater is released in natura into the São Gonçalo watercourse. These data were corroborated by the autonomous sanitation service of the city of Pelotas.

Such attitudes can generate a decrease in the capacity of self-purification of the water body because industrial and urban sewage contains organic material rich in nutrients. In addition, these punctual sources of pollution lead to a decrease in water quality and an intense process of eutrophication (KIELING-RUBIO et al., 2015).

Due to the problems of sedimentation, eutrophication and environmental degradation of aquatic systems involving watercourses, lakes and reservoirs, the identification and classification of areas supplying substances such as organic matter, nitrogen and phosphorus, is of great importance in the planning and adoption of diffuse pollution control measures resulting from local pollution (STEINKE, 2008). An option for identifying polluting groups is statistical programs and the recognition of each area of the mentioned water body.

Multivariate statistical methods provide a simple interpretation based on the analysis of complex data, which could help to better understand the behavior of the water body. The methods also allow identifying possible factors or sources responsible for the variations in the water quality of springs. This type of analysis allows reducing the information contained in a number of original variables to a smaller set of statistical variables (factors) with minimal loss of information (HAIR et al., 2009).

Grouping objects consists of recognizing among them a degree of similarity sufficient to bring them together in the same set. The choice for the grouping method is as critical as choosing association coefficients. It depends on the correct classification of a sample within one or another group already formed (FÁVERO et al., 2015).

Based on the grouping of water analysis data from the Lagoa Mirim watershed, it is possible to perform an interpretation of each group of pollutants, thus indicating possible activities, anthropogenic or not, to each of these groups.

Thus, the objective of this work was to use multivariate statistical methods, such as analysis of main components, to analyze the data obtained by the analysis of the Lagoa Mirim, and thus to establish the most significant variables in a monitoring plan, relating them to causes of contamination.

\section{METHODOLOGY}

\section{Region of Study}

This research was developed in the Lagoa Mirim (Figure 1). It is located between the extreme south 
of Brazil and the north of Uruguay in the coastal plain of Rio Grande do Sul. It connects to Lagoa dos Patos through the São Gonçalo watercourse. It is the second largest water body with lacustrine characteristics in Brazil, with an area of $3,749 \mathrm{~km}^{2}$ (OLIVEIRA et al., 2015).

\section{Water Quality Monitoring}

The data originated from the Lagoa Mirim water quality monitoring carried out by the Lagoa Mirim Development Agency. Twenty-two collections that occurred monthly over a three-year period (2014, 2015 and 2016) were performed at eight monitoring points, as described in Table 1. These points comprise both sides of the lagoon, as presented in Figure 1.

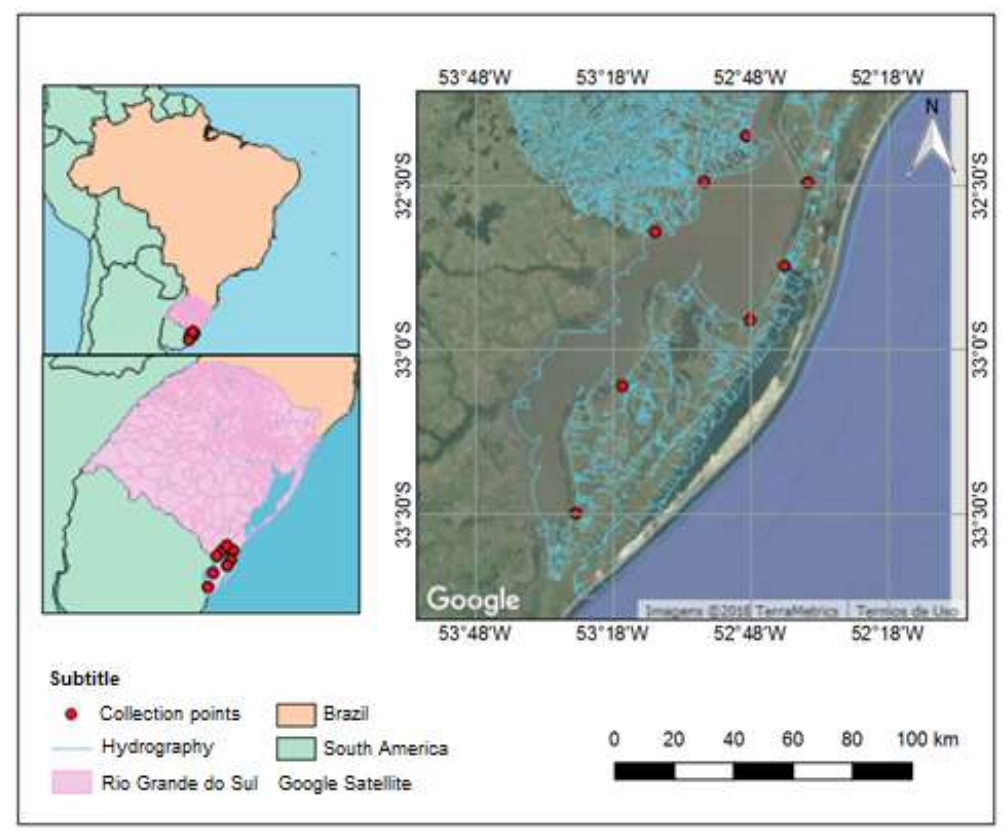

Figure 1: Location of Lagoa Mirim: monitoring points of the Lagoa Mirim water quality.

Table 1: Monitoring points of the water quality of Lagoa Mirim

\begin{tabular}{llll}
\hline LM1 & Identification & Coordinates & \\
LM2 & Praia Pontal & $32^{\circ} 20^{\prime} 052^{\prime \prime}$ & $052^{\circ} 49^{\prime} 21,5^{\prime \prime}$ \\
LM3 & Fazenda Bretanha & $32^{\circ} 29^{\prime} 14,0^{\prime \prime}$ & $052^{\circ} 58^{\prime} 14,9^{\prime \prime}$ \\
LM4 & Fazenda São Francisco & $32^{\circ} 38^{\prime} 25,6^{\prime \prime}$ & $053^{\circ} 08^{\prime} 56,8^{\prime \prime}$ \\
LM5 & Capilha & $32^{\circ} 29^{\prime} 23^{\prime \prime}$ & $052^{\circ} 35^{\prime} 33^{\prime \prime}$ \\
LM6 & Curral Alto & $32^{\circ} 44^{\prime} 47.41^{\prime \prime}$ & $52^{\circ} 40^{\prime} 35.99^{\prime \prime}$ \\
LM7 & Vila Anselmi & $32^{\circ} 54^{\prime} 31^{\prime \prime}$ & $052^{\circ} 48^{\prime} 08^{\prime \prime}$ \\
LM8 & Salso & $33^{\circ} 06^{\prime} 34^{\prime \prime}$ & $053^{\circ} 16^{\prime} 06^{\prime \prime}$ \\
\hline
\end{tabular}

The samples collected were analyzed by the Water Laboratory of the Lagoa Mirim Development Agency at the Federal University of Pelotas. Ten variables were analyzed: dissolved oxygen (DO), biochemical oxygen demand (BOD5), $\mathrm{pH}$, electrical conductivity, turbidity, total phosphorus, Kjeldahl total nitrogen (KTN), total solids (TS), and thermotolerant coliforms. The variable temperature was measured locally, and the other laboratory analyses followed the methodology described by APHA (2017).

\section{Statistical Analysis}

The results for the variables were standardized in order to avoid that their order of magnitude 
influenced the considerations made in this study in relation to a variable of a smaller scale. This standardization was done by dividing the mean deviations of each variable $(\mathrm{X}-\bar{X})$ by the standard deviation $S(X)$, where $Y$ is the standardized value according to equation I (WILKS, 2006):

$$
\text { (Equation I) } \quad Y=\frac{x-R}{S(x)}
$$

The data used to conduct the statistical analyses refer to the annual averages of the variables regarding the collections in each monitoring point. To perform all statistical tests, as well as for the AF/ACP, the Excel ActionStat software was used.

To confirm if the data used in this study followed a normal distribution, the Kolmogorov-Smirnov (KS) test was used. With a $95 \%$ confidence interval, it was possible to confirm that the data followed a normal distribution. The Kaisere-Meyere-Olkin (KMO) and Bartlett tests were used to evidence that the data analyzed were compatible with principal component analysis (PCA). After the tests were carried out, a KMO value of 0.517 was obtained. This value is above the minimum accepted by Hair et al. (2009), which defined 0.5 as the minimum level of suitability. This test verifies if the data is sufficient for the desired analysis according to a value between 0 and 1 . The better result is the closest to 1 . The Bartlett test is used to determine if there is enough correlation between variables. Discarding, through the Bartlett test, the null hypothesis, when the correlation coefficient equals zero, we can state that the data sample is consistent with a factorial analysis (BILGIN, 2015).

Once the normal distribution of data and their compatibility with a factorial analysis were confirmed, the main components were analyzed. This analysis is conducted by calculating eigenvalues and corresponding eigenvectors of a correlation matrix $[R]$, where the elements of the main diagonal represent the variances of standardized absolute frequencies of each class. Covariance values between pairs of standardized variables are represented by the other elements of [R] (SILVESTRE et al., 2013).

Table 2: Matrix of correlation of water quality variables of the Lagoa Mirim.

\begin{tabular}{|c|c|c|c|c|c|c|c|c|c|c|}
\hline Temperature & Conductivity & Phosphorus & KTN & Coliforms & BOD & $\mathrm{DO}$ & Turbidity & $\mathrm{pH}$ & TS & \\
\hline Temperature & 1.000 & & & & & & & & & \\
\hline Conductivity & -.507 & 1.000 & & & & & & & & \\
\hline Phosphorus & -.034 & -.090 & 1.000 & & & & & & & \\
\hline KTN & -.516 & .000 & .417 & 1,000 & & & & & & \\
\hline Coliforms & -.120 & .429 & -.037 & -.204 & 1.000 & & & & & \\
\hline BOD & .083 & -.207 & .271 & .032 & -.180 & 1.000 & & & & \\
\hline DO & .550 & -.406 & -.192 & -.492 & -.150 & .482 & 1.000 & & & \\
\hline Turbidity & -.134 & -.030 & .767 & .404 & .154 & .062 & -.323 & 1.000 & & \\
\hline $\mathrm{pH}$ & -.556 & -.050 & .360 & .794 & -.065 & -.209 & -.649 & .407 & 1.000 & \\
\hline TS & -.183 & .174 & .394 & .311 & -.053 & .266 & -.094 & .642 & .015 & 1.000 \\
\hline
\end{tabular}

The main components are obtained in descending order of maximum variance, i.e., they are calculated so that the maximum total variability of the data is explained by the first main component, and the second explains the maximum of the remaining variability of the data and is not correlated with the first, and so on, reaching a number of principal components that is at most equal to the number of variables (ROCHA et al., 2016).

A correlation matrix is used to suppress the problem of scales and the different units in which the 
variables are measured. It is important to note that the matrix of the main components is not always easy to interpret because the results of the analyses are close to the mean values (ROCHA et al., 2016).To solve this problem, we used the orthogonal rotation procedure of the matrix, generating a new matrix that presents a better interpretative meaning to components. For the purposes of this research, the Varimax method was used to perform the orthogonal rotation of the correlation matrix, according to Table 3.

The analyzed variables were grouped to evaluate the water quality of the Lagoa Mirim. Multivariate statistical analysis - Factor Analysis/Principal Component Analysis (FA/PCA) - were used. To perform FA/PCA, the following steps are carried out: preparation of the correlation matrix, extraction of the common factors and, finally, rotation of the axes corresponding to the common factors. This is done in order to simplify the solution for an easier interpretation (HAIR et al., 2009).

\section{RESULTS AND DISCUSSION}

The first step of the factorial analysis consists in designing the correlation matrix of the studied variables. The correlation matrix (Table 2 ) shows that only coliform and BOD variables did not correlate coefficients greater than 0.5 (in modulus) with any other variable. For all other variables, this coefficient is higher. The temperature was the variable with the highest number of correlation coefficients higher than 0.5 (four). Correlation coefficients higher than 0.5 (in module) show that there was a strong correlation between the considered variables (SOUSA et al., 2018).

There was a strong correlation, with respect to the variable temperature, with conductivity $(0.507)$, KNT (0.517), DO (0.550), and pH (0.556). The variable $\mathrm{pH}$ was another variable that showed a higher number of strong correlations, (0.556), KNT (0.794), and DO (0.649). This relation between pH and KNT was the strongest correlation found in the correlation matrix of the variables in this study. The variables conductivity and phosphorus presented a strong correlation with only one variable (conductivity and temperature, respectively).

The second phase of the FA/PCA is the extraction of common factors (main components). In the third stage, the matrix of common factors generated in step 2 is rotated. The matrix of the main components is rotated in order to generate a new matrix that presents a better interpretative meaning for the components. This matrix can be visualized in Table 3 .

The best behavior of Lagoa Mirim water quality variables can be demonstrated by four components (Table 3). This number of components was chosen so that the total cumulative variance was between 70 and $90 \%$, which brings a proper representation of the original variance. As a criterion for the selection of the number of components, a total cumulative variance of $80 \%$ was adopted.

This number of principal components, as well as their accumulated variances, are consistent with the results found by Rocha (2016). In his research on a spring from Juiz de Fora using the same statistical methodology, a factorial weight matrix was generated with three main components, also rotated by the Varimax algorithm, with a total accumulated variance above $70 \%$. 
Table 3: Main Components.

\begin{tabular}{lllll}
\hline & 1 & 2 & 3 & 4 \\
Temperature & -.763 & .074 & -.509 & -.114 \\
Electric conductivity & .153 & -.090 & .911 & -.015 \\
Phosphorus & .185 & .851 & -.148 & .093 \\
KNT & .854 & .305 & -.117 & .112 \\
Coliforms & -.274 & .199 & .649 & -.413 \\
BOD & -.152 & .167 & -.142 & .834 \\
DO & -.682 & -.184 & -.321 & .465 \\
Turbidity & .190 & .946 & .056 & -.034 \\
pH & .862 & .253 & -.153 & -.271 \\
TS & .109 & .627 & .290 & .494 \\
\hline Eigenvalue & & & & \\
\% variance explained & 27.228 & 22.847 & 17.810 & \\
\% cumulative variance & 27.228 & 50.075 & 67.885 & \\
\hline
\end{tabular}

Table 3 shows that the four main components explained $82.238 \%$ of the variance of the original variables. These four components evidenced the relationship between factors and the variables and provided subsidies to identify the variables that were more representative in each component. The high values of factorial weights showed which variables are the most significant for each of the major components.

The first component explained $27.228 \%$ of the variance of data and was associated with four variables: temperature, $\mathrm{KNT}, \mathrm{DO}$, and $\mathrm{pH}$. KNT and $\mathrm{pH}$ had the highest weight. These variables were related to non-point sources of pollution. The negative relationship between KNT and DO parameters can be explained by the dependence of DO on ammonium oxidation processes into nitrate and nitrite forms. Wang et al. (2013) found similar results in a case study on the Songhua River in China. The fact that parameters such as BOD and thermotolerant coliforms, indicative of point pollution, are were not present in this component corroborates that it is related to diffuse sources of pollution. The Mirim-São Gonçalo watershed is responsible for a great water demand due to extensively cultivated areas of irrigated rice that stand out in planted area when compared to other crops. According to IRGA (2018), the Lagoa Mirim and the watercourse São Gonçalo Canal allow the irrigation of a total area of approximately 180,000 ha of agricultural crops, mainly irrigated rice. The cultivation of irrigated rice has been pointed out as a crop with a high polluting potential of water sources in the south of Brazil. This is because irrigation favors the transport of pesticides through drainage and leaching (SILVA et al., 2009; GRUTZMACHER et al., 2008).

The component 2 explained, $22.847 \%$ of the variance, and had phosphorus, turbidity and TS as explanatory variables. The most representative variable was turbidity. As shown in Table 3, these variables were positively related to each other. These variables can also be associated with pollution by agricultural activities. In samples collected in affluent water bodies of Lagoa Mirim, Fia et al. (2009) found phosphorus concentrations higher than the limits established by the environmental legislation. This was reported by the authors as resulting from the intense agricultural activity of the region, which may be associated with the use of phosphate fertilizers.

The main components 3 and 4 explained, respectively, $17.810 \%$ and $14.353 \%$ of the data variability. The representative variables were conductivity and coliforms for PC3, and only BOD for PC4. The variables in both these main components can be associated to organic matter pollution from untreated effluents, as 
indicated by the concentration of BOD and thermotolerant coliforms. The presence of coliforms at sampling points of the Lagoa Mirim was found by Tormam et al. (2017), who associated this contamination mainly with the discharge of domestic sewage.

Due to the rotation of the matrix of main components using the Varimax algorithm, there are no common variables among the main components. The reference value to classify the variables as significant for each PC was 0.6. Therefore, all variables that exceeded this value (in module) were considered as having a strong relation with the main component to which they referred.

\section{CONCLUSIONS}

The factorial analysis allowed classifying the variables with a greater significance in water quality, prioritizing those related to each other. The grouping analysis classified water sources according to water quality. This study showed that it is possible to use statistical methods such as correlation matrix and the Pearson test to analyze variables for the monitoring of the Lagoa Mirim. For the most part, the variables present a strong correlation with each other, confirming the importance of the analysis of such variables and attesting the relevance of using statistical methods for the monitoring of this watershed. It can also be concluded that it was possible to identify groups of pollutants and assess to which activities these groups may be associated, showing the relevance of such a statistical tool.

\section{REFERENCES}

ALBERTONI, E. F.; SILVA, C. P.; TRINDADE, C. R.; FURLANETTO, L. M.. Water quality of the São Gonçalo channel, urban and agricultural water supply in southern Brazil. Revista Brasileira de Recursos Hídricos, Porto Alegre, v.22, n.2, 2017. DOI: http://dx.doi.org/10.1590/2318$\underline{0331.011716082}$

APHA. American Public Health Association. Standard methods for the examination of water and wastewater. 23 ed. Washington: APHA, 2017.

BILGIN, A.. An assessment of water quality in the Coruh Basin (Turkey) using multivariate statistical techniques. Environmental Monitoring and

Assessment, v.187, n.721, 2015. DOI: https://doi.org/10.1007/s10661-015-4904-9

FÁVERO, L. P.; BELFIORE, P.. Análise de Dados: Técnicas Multivariadas Exploratórias com SPSS e STATA. São Paulo: Elsevier, 2015.

HAIR, J. F.; BLACK, W. C.; BABIN, B. J.; ANDERSON, R. E.; TATHAM, R. L..Análise multivariada de dados. 6 ed. São Paulo: Bookman, 2009.

FIA, R.; MATOS, A. T.; CORADI, P. C.; PEREIRA-RAMIREZ, O. Estado trófico da água na bacia hidrográfica da Lagoa Mirim, RS, Brasil. Ambiente \&Á gua-An Interdisciplinary Journal of Applied Science, Taubaté, v.4, n.1, p.132-141, 2009.DOI: http://doi.org/10.4136/ambi-agua.78
GRÜTZMACHER, D. D.; GRÜTZMACHER, A. D; AGOSTINETTO D.; LOECK, A. E.; ROMAN, R.; PEIXOTO, S. C.; ZANELLA, R.. Monitoramento de agrotóxicos em dois mananciais hídricos no sul do Brasil. Revista Brasileira de Engenharia Agrícola e Ambiental, Campina Grande, v.12, n.6, p.632-637, 2008. DOI: https://doi.org/10.1590/S1415-43662008000600010

IRGA. Instituto Rio Grandense do Arroz. Produtividades municipais safra 2016/17. Porto Alegre: IRGA, 2017.

KIELING-RUBIO, M. A.; BENVENUTI, T.; COSTA, G. M.; PETRY, C. T.; RODRIGUES, M. A. S.; SCHMITT, J. L.; DROSTE, A.. Integrated environmental assessment of streams in the Sinos River basin in the State of Rio Grande do Sul, Brazil. Brazilian Journal of Biology, São Carlos, v.75, n.2, p.105-113, 2015. DOI: https://doi.org/10.1590/1519-6984.1013

MARMONTEL, C. V. F.; RODRIGUES, V. A.. Parâmetros Indicativos para qualidade da água em nascentes com diferentes coberturas de terra e conservação da vegetação ciliar. Floresta e Ambiente, Seropédica, v.22, n.2, p.171-181, 2015. DOI: https://doi.org/10.1590/2179-8087.082014

OLIVEIRA, H. A.; FERNANDES, E. H. L.; MÖLLER JUNIOR, O. O.; COLLARES, G. L.. Processos hidrológicos e hidrodinâmicos da Lagoa Mirim. Revista Brasileira de Recursos Hídricos, Porto Alegre, v.20, n.1, p.34-45, 2015.

PIMENTA, R. H. O.; REIS, S. P.; FONSECA, M.. Diagnóstico ambiental em três trechos distintos do córrego Capão Regional Venda Nova, município de Belo Horizonte, MG. Revista Petra, v.2, n.1, p.153-173, 2016. 
ROCHA, C. H. B.; PEREIRA, A. M.. Análise multivariada para seleção de parâmetros de monitoramento em manancial de Juiz de Fora, Minas Gerais. Revista Ambiente \& Água, Taubaté, v.11, n.1, p.176-187, 2016. DOI: https://doi.org/10.4136/ambi-agua.1590

SILVA, L. C.. Plano de gestão ambiental e social. Programa de desenvolvimento municipal integrado, 2007.

SILVA, D. R. O. D.; AVILA, L. A. D.; AGOSTINETTO, D.; DAL MAGRO, T.; OLIVEIRA, E. D.; ZANELLA, R.; NOLDIN, J. A.. Monitoramento de agrotóxicos em águas superficiais de regiões orizícolas no sul do Brasil. Ciência Rural, Santa Maria, v.39, n.9, p.2383-2389, 2009. DOI: https://doi.org/10.1590/S0103-84782009000900001

SILVESTRE, M. R.; SANT'ANNA NETO, J. L.; FLORES, E. F.. Critérios estatísticos para definir anos padrão: uma contribuição à climatologia geográfica. Revista Formação, v.2, n.20, p.23-53, 2013.

SOUSA, G. B.; CAMPOS, L. P.; JUNIOR, J. F. S.; GUIMARÃES, G. S. C.. Parâmetros físico-químicos das águas da bacia do rio Gurguéia, Piauí-PI. Revista Brasileira de Gestão Ambiental, Pombal, v.12, n.1, p.01-06, 2018.
SOUZA, M. F.; MEDRONHA, G. A.; MILANI, I. C..

Monitoramento da qualidade da água de um manancial hídrico sob influência de atividades antrópicas, no município de pelotas, RS-Brasil. In: SIMPÓSIO BRASILEIRO DE RECURSOS HÍDRICOS. Anais. 2013.

STEINKE, V. A.; SAITO, C. H.. Exportação de carga poluidora para identificação de áreas úmidas sob risco ambiental na bacia hidrográfica da Lagoa Mirim. Sociedade \& Natureza, Uberlândia, v.20, n.2, p.43-67, 2008. DOI: https://doi.org/10.1590/S1982-45132008000200003

TORMAM, M. F.; BORK, C. K.; GUEDES, HUGO A. S.; MANZKE, J. S.; FERRAO, A. L. L. C.. Variabilidade sazonal da qualidade da água na Lagoa Mirim, RS, Brasil. Revista Brasileira de Engenharia e Sustentabilidade, v.4, n.2, p.54-59, 2017. DOI: http://dx.doi.org/10.15210/rbes.v4i2.12245

WANG, Y.; WANG, P.; BAI, Y.; TIAN, Z.; LI, J.; SHAO, X.; MUSTAVICH, L. F.; LI, B. L.. Assessment of surface water quality via multivariate statistical techniques: A case study of the Songhua River Harbin region, China. Journal of Hydroenvironment Research, v.7, n.1, p.30-40, 2013. DOI: https://doi.org/10.1016/i.jher.2012.10.003

WILKS, D. S.. Statistical Methods in the atmospheric sciences. 2 ed. International geophysics series 91, 2006.

A CBPC - Companhia Brasileira de Produção Científica (CNPJ: 11.221.422/0001-03) detém os direitos materiais desta publicação. Os direitos referem-se à publicação do trabalho em qualquer parte do mundo, incluindo os direitos às renovações, expansões e disseminações da contribuição, bem como outros direitos subsidiários. Todos os trabalhos publicados eletronicamente poderão posteriormente ser publicados em coletâneas impressas sob coordenação da Sustenere Publishing, da Companhia Brasileira de Produção Científica e seus parceiros autorizados. Os (as) autores (as) preservam os direitos autorais, mas não têm permissão para a publicação da contribuição em outro meio, impresso ou digital, em português ou em tradução. 